\title{
Military in Politics in Brazil in Critical Terms
}

\author{
Vinicius Mariano de Carvalho \\ Anna Isabella Grimaldi
}

\begin{abstract}
Theoretically and practically speaking, the Western understanding of military professionalism and civil-military relations still reflects the framework that the political scientist Samuel Huntington articulated in his 1957 book, The Soldier and the State. It was in this work that Huntington presented his concept of objective control of the military, which requires that military leadership and political leadership commit to a strict separation of spheres. The military are responsible for the expertise in the management of violence, while civilians struggle with the political dimensions of the use of force. Circumscribed in their respective spheres, each side complements and respects the domain of the other (Huntington, 1996). From this point of departure, much theory and scholarship has been developed, all of which repeats the mantra of 'civilian political control over the armed forces'.
\end{abstract}

In the May/June 2021 issue of Foreign Affairs, Risa Brooks (with Jim Golby and Heidi Urben) published an article titled "Crisis of Command - America's Broken Civil-Military Relationship Imperils National Security." The text begins by saying:

Civilian control over the military is deeply embedded in the U.S. (...) But over the past three decades, civilian control has quietly but steadily degraded. Senior military officers may still follow orders and avoid overt insubordination, but their influence has grown, while oversight and accountability mechanisms have faltered.

In the text, Brooks emphasizes the extent to which this degradation of civilian control over the military represents a risk for the American model of democracy. She also points out the extent to which this degradation damages the image of the military, as it gradually deconstructs the positive image that they have built over the years.

Continuing the topic of military involvement in political issues, in France, on May 20, 2021, a group of 1,200 retired officers, including 24 generals, with the anonymous adhesion of two dozen active military of the French Armed Forces, wrote a letter with clear political content. The declaration had an immense impact on the French political environment and sparked warning signs about the risk of the military speaking out on issues related to the country's civilian political conduct.

It appears that the Pax Huntingtoniana has been broken or is weakened. This provokes great public and academic debate, which is certainly positive, since it induces us to rethink the parameters around which we build the critical edifice of civil-military relations, and leads us to readjust the 
terms and concepts we use to relate to contemporary realities, something quite different from the post-World War II and Cold War context in which Huntington formulated his thinking.

In the context of Brazil, we are witnessing an increasing and worrying degree of military presence in political spheres of power today (Amar, 2018; Corrales, 2019). Several superior officers, both active and retired, have secured ministerial positions under the current government, while public institutions are populated by junior officers. Academia and civil society alike are questioning the potential implications of such levels of militarization within a democracy (Diamint, 2015; PionBerlin \& Acácio, 2020), especially in a country still under the shadows of a military regime (19641985). Military involvement in Brazil's politics, however, dates back to the origins of the Brazilian Republic itself and civil-military relations in Brazil did not develop in the same way as in Europe or North America.

Literature and research on the Brazilian Military regime, re-democratization, and civilmilitary relations in Brazil is consolidated and robust (Castro, 2000; Bruneau \& Tollefson, 2014; Stepan, 2015), however, there still lacks a multidisciplinary approach to understand the pervasive presence of the military in the Brazilian political arena from a broader historical perspective. Considering these particularities and context of Brazilian civil-military relations and the involvement of military in the politics in the country, a research network was created at King's College London in 2020, with a project that builds towards a comprehensive and multidisciplinary analysis of public perceptions of the military from the beginning of the Brazilian Republic to the present day (http://www.brazilinstitute.org/military-in-politics-in-brazil-network). The aim of this project is to understand how the military developed such a highly contentious position within Brazil's socio-political history through populism, authoritarianism, during the re-democratization period, and under the current government.

In May, 2021, the Research Network called for an international conference ${ }^{1}$ to analyse military relations in the politics in Brazil. The conference took a multidisciplinary approach to address questions such as:

- What does it mean to have military forces at the centre stage of a nation's historical trajectory and construction?

- How does the presence of such an entity influence the social imaginary of a people?

- What impacts does the presence of the military have on Brazil's domestic and foreign politics?

- What conceptual and methodological tools might we use to better understand civil-military relations in Brazil?

\footnotetext{
${ }^{1}$ The proceedings of the conference are summarised here: http://www.brazilinstitute.org/mpb-conference
} 
This Special Issue of Brasiliana - Journal for Brazilian Studies brings together many of the academic contributions that were discussed and presented at the conference. This issue is therefore the first published contribution of the Research Network towards broader scholarship on the area of civil-military relations in Brazil. The articles published here attempt to answer to the questions listed above, connecting the dots between various historical periods. The Issue brings together articles from the fields of political science, civil-military relations, history, sociology, and collective memory. They take an inductive approach to combine qualitative media, discourse, and narrative analysis and build a history of the social and political role of the military in Brazil.

What the articles of this issue have demonstrated is that the topic of the military in politics in Brazil is being discussed from several specific perspectives, all of which demand careful and finegrained research, as well as a more holistic and comprehensive approach. They reveal that the concepts and definitions used in the scholarship of the Global North need fine-tuning in order to precisely understand the phenomenon.

\section{Compared perspectives}

The first point to consider when discussing civil-military relations and the involvement of the military in politics in Brazil today is that there is no single way of defining what they are or how civil-military relations are established and consolidated. According to Rukavishnikov \& Pugh, "in each country the answer to this question is deeply influenced by national history, sentiments and traditions" (2006, 131). Unique factors and historical experiences mean that, at the most basic level, terms like 'military' and 'civil' are understood differently in Brazil, making the idea of civil-military relations in Brazil even more distinct. Yet in the same text, Rukavishnikov \& Pugh state that "[t]he very nature of the problem is permanently changing because both society and the military are constantly changing as well" $(2006,131)$. This is an extremely relevant factor: a conceptual apriorism, not nuanced, may disturb the analysis of the phenomenon, especially considering that the phenomenon analyzed is dynamic by nature.

That said, it is clear that when studying this topic of civil-military relations, what one must have in mind is a clear definition of concepts, above all to avoid over-simplification and generalization. And from this clear definition, one can understand, contextually, what civil-military relations are. The two most important concepts are, obviously, 'civilian' and 'military'. What is a civilian? Rukavishnikov \& Pugh (2006) point to some of the fundamental elements to be consider: is it "people without arms"? Or does the term civilian refer instead to democratically elected governments? Another way we might understand it is by referring to public bureaucracy, or even the political class. But it might also be understood as public opinion. More broadly, perhaps 'civilian' can be considered a combination of all these elements. 
The other term to define is 'military'. In relation to the civilian, could we consider the military to be the "people with arms"? Is it a profession like any other? Or is it a public service career? Would it be an existential condition, like that of a priest, whose ordination implies an 'indelible mark on the soul' and therefore transforms a person ontologically speaking? Or is it just service to a nation? Answers to these questions will certainly vary greatly from country to country. Even within a country the topic remains controversial, since these two entities - the civil the military - have often been constituted in ways that are problematic, traumatic, and that have taken places in processes of conflict. And also, because, as pointed above, both, civil and military are, socially and historically, constantly changing.

Other distinctions and definitions are necessary and fundamental in this context. The distinction and precision of what is meant by terms such as 'defence' and 'military'. Although part of the same semantic field, not everything related to defence belongs to the military sphere, yet everything that is military must be encapsulated by the framework of defense. In this sense, it can be said that the military attribute refers to a trained professional to carry out weapon-based tasks when required for national defence. Other actors, however, also compete for this national defence and are not, and should not be, military. In fact, all actors in a nation compete for the national defence. In this way, it is not necessary to be a soldier (even better if it is not) to be in political charge of the defence, of the management of national defence. In other words, 'military' refers to specific technical knowledge, while 'defence' refers to a political exercise that is not limited to a specific technical element.

Here I touch on another point that must be clearly defined: What is meant by "military professionalism"? This term alone could occupy an entire text, and this is not the objective here. The important thing to note about the concept of military professionalism is that the answer to this question is directly related to how a country understands the role of the military. And the answers are many: nation building? National defence? Regime defence? The answer to this will obviously depend on how the socio-historical-cultural processes of each country have resorted to the military actor in the past.

In an excellent text entitled 'Lost in Translation - The challenges of exporting models of civilmiltiary relations', Laura Cleary (2012) points out precisely how much conceptual clarity is needed, as well as how to avoid transposing models simply because they 'worked' in another country. The main term that Cleary draws attention to is the idea of 'civilian control' over the military. She convincingly explains how the word 'control' has diverse semantic value, which hierarchizes and, consequently, I add, does not apply to a 'relationship'. Civil-military relations cannot be constituted with hierarchies.

The word 'control' carries meaning that can distract the understanding of what civil-military relations should be in modern democracies. From my perspective, the word 'accountability' better 
describes this relationship; accountability understood as 'rendering of account', as 'responsibility'. Civil-military relations in modern democracies must be guided by a principle of mutual responsibility. Here, responsibility is applied in the etymological sense of the term: the capacity and availability to give answers. Civil-military relations cannot allow for a hierarchy between these two terms. I turn again to Rukavisnikov \& Pugh: “...the entire set of issues relating to civil-military relations cannot be reduced to the political control of armed forces" (134).

\section{Military and politics}

Another key and problematic point addressed through the Research Network has been the participation of the military in politics, and the 'politicization' of the military. Again, this is a controversial matter that does not have a single, objective answer considered valid for everyone. In modern democracies, the basic idea is that the military is an institution of the state - not of governments - and that, because they serve the state, they must be 'apolitical'. But it is also fundamental right in modern democracies that every citizen is a political actor that has the right to participate in the exercise of politics (although there are countries that do not allow their military to vote).

It seems important to me that if understood as individuals, those military professionals are political actors. However, the military as an institution cannot be 'partisan', under penalty of transforming itself into a party. This would unbalance the balance of democracy, particularly given the military acts as the armed representation of the state. Civil-military relations must understand that the military people, as individuals, are political actors and for their exercise of their political rights as citizens, their participation in the politics must be normalize (in the sense of creating norms). This does not mean that the military institutionally should hold bureaucratic power in institutions. This would make them transcend their professional function, the function for which they are required in modern democracies.

Military have not the function of keeping governments under control, either. It is not the role of the state military apparatus to oversee governments, nor to act as moderators of the political environment. On the contrary, it is through civil democratic political debate, expressed in parliaments and in state bureaucracy, that national defence policies and strategies are established, and towards which ends the military are one of the executors. Military personnel can have a voice in this debate, but as professionals, not as supporters or partisans.

On May 13, 2021, the Chief of Staff of the French Armed Forces, Gen François Lecointre, presented his resignation. This dismissal has provoked significant speculation, especially after the recent event of the French military's political demonstration, mentioned above. In an interview with Le Grand Jury RTL-LCI-Le Figaro, the general stated: 
La première raison était d'éviter qu'il y ait une politisation de la fonction du chef d'étatmajor des armées. Je ne souhaitais pas que que le chef d'état-major des armées parte à l'issue du mandat d'un président de la République, (...) je ne souhaitais qu'un chef d'état-major des armées, qui est un chef militaire, soit associé à un politique.

The General's perception seems prudent, if this is indeed his reason for leaving the post. It is necessary to understand that military intuitions are not political institutions and consequently the management of their preparation and employment should not be linked to a government. Changes in command in the armed forces cannot be understood as political positions, but as a result of the internal hierarchical professional process. The same does not apply to the role of a Minister of Defence, for example, this post is political and not professional, technically speaking.

In the continuation of the same interview, Gen Lecointre says something that I think is also important to emphasize. He literally says:

Ce qui me frappe, ce n'est pas le cas particulier du président de la République, c'est le cas de l'ensemble de la classe politique aujourd'hui, c'est le cas de l'ensemble des journalistes, c'est que vous ne connaissez rien aux armées, parce que vous ne connaissez pas le cœur des armées [...].

The general is partially right. There is a great lack of knowledge on the part of civilian elites about what the armed forces are. It might even be considered natural. As totalizing institutions, like religious orders, the armed forces tend to maintain an esprit de corps that often exclude non-members. This, however, cannot be used as an excuse for the lack of relations with the civilian world. For the civil-military pair to be relational, they must be distinguished and understood as different. Not competitors, but complementary to democratic societies. It is not expected that one occupies the role of the other, but that they actually complement each other, for the good of the defense of the state.

In this sense, it is necessary to avoid the risk of mythologizing what the military or its function. In many countries, and in Brazil in particular, armed forces are viewed very positively by society at large. While political institutions often suffer from disbelief and distrust. This can lead to what I call the 'mythologization' that the military are, by nature, more reliable than civilians in dealing with public affairs. The first important lesson to be drawn from this is that if the military begins to take on the role of what are civilian activities, it will inevitably suffer from the same disbelief that civilian powers are victims of.

Civil-military relations are not those in which the military occupies the role that civilians should play in society. Neither are those in which civilians place responsibilities on the military that are theirs for the execution of public policies. In this relationship, breaking the hierarchy is fundamental. Military personnel need to understand that serving in uniform does not make them 
better citizens than those who do not. Nor are they efficient and capable of carrying out all the functions of the exercise of civil power, especially with regard to the execution of public policies. In the same way, civil actors, especially politicians, must remember that it is not resorting to the military to implement any and all public policies that will contribute to a harmonious civil-military relationship and, above all, demonstrate efficiency in their management. Military professionalism essential in modern democracies - cannot be confused with civic professionalism. Nor is it hierarchical in relation to this one.

These are the conceptual ideas that have in many ways guided the direction of the articles present in this special issue, and I believe they are highly relevant to the times in which we live.

I would like to end with a reference to Mustafa Kemal, later Kemal Ataturk, the founder of the Turkish republic, who at a meeting of his party, the Committee for Union and Progress, in 1909 in Thessaloniki, stated:

As long as officers remain in the Party we shall build neither a Strong Party nor a strong Army. In the $3^{\text {rd }}$ Army most of the officers are also member of the Party and the $3^{\text {rd }}$ Army cannot be called first-class. Furthermore the party, receiving its strength from the Army, will never appeal to the nation. (apud Lerner e Robinson, 1960)

May these words echo in our understanding of the role of civil-military relations and in our understanding of military involvement in politics, and may this special issue contribute to this debate.

\section{References}

Amar, P. (2018) Military Capitalism, NACLA Report on the Americas, 50:1, 82-89, DOI: 10.1080/10714839.2018.1448601

Brooks, Risa Brooks; Golby, Jim; and Urben, Heidi. "Crisis of Command - America's Broken Civil-Military Relationship Imperils National Security." Foreign Affairs May/June 2021:

https://www.foreignaffairs.com/articles/united-states/2021-04-09/national-security-crisis-command

Bruneau, T.C., and Tollefson, S.C. (2014), Civil-Military Relations in Brazil: A Reassessment, in: Journal of Politics in Latin America, 6, 2, 107-138.

Castro, C. (2000) The Military and Politics in Brazil: 1964-2000. Centre for Brazilian Studies, University of Oxford.

Cleary, Laura R. "Lost in Translation: The Challenge of Exporting Models of Civil-Military Relations." PRISM 3, no. 2 (2012): 19-36. Accessed July 31, 2021. https://www.jstor.org/stable/26469726.

Corrales, J. (2019) Latin America Risks Becoming the Land of Militarized Democracies, Americas Quarterly, 24 October 2019.

Diamint, R. (2015). A New Militarism in Latin America. Journal of Democracy, (4), 155-168.

S RASILIANA: Journal for Brazilian Studies. Vol 10, No. 1, 2021. ISSN 2245-4873. 
Huntington, Samuel. O Soldado e o Estado. Rio de Janeiro: BibliEx, 1996. (Col. General Benício, v. 317)

Le Grand Jury RTL-LCI-Le Figaro, 13 Juin 2021.

https://www.rtl.fr/actu/politique/armees-je-quitte-mes-fonctions-annonce-le-general-lecointre-chef-d-etatmajor-7900044440

Lerner, Daniel, and Richard D. Robinson. "Swords and Ploughshares: The Turkish Army as a Modernizing Force." World Politics 13, no. 1 (1960): 19-44. Accessed July 31, 2021. doi:10.2307/2009261.

Pion-Berlin, D., \& Acácio, I. (2020). The Return of the Latin American Military? Journal of Democracy 31(4), 151-165. doi:10.1353/jod.2020.0062.

Rukavishnikov V.O., Pugh M. (2006) Civil-Military Relations. In: Caforio G. (eds) Handbook of the Sociology of the Military. Handbooks of Sociology and Social Research. Springer, Boston, MA. https://doi.org/10.1007/0-387-34576-0_8

Stepan, A. (2015). The Military in Politics: Changing Patterns in Brazil. Princeton University Press.

B RASILIANA: Journal for Brazilian Studies. Vol 10, No. 1, 2021. ISSN 2245-4373. 